Insight, part of a Special Feature on Do we need new management paradigms to achieve sustainability in tropical forests?

\title{
Considering Background Condition Effects in Tailoring Tropical Forest Management Systems for Sustainability
}

\author{
David S. Hammond $^{1}$ and $\underline{\text { Roderick J. Zagt }}^{2}$
}

\begin{abstract}
Systems devised for managing tropical forests sustainably have yet to prove successful. In many instances, they have fallen short of initial prospects, but the reasons for these shortfalls are often not apparent. Here, we explore factors that can shape the likelihood of success, collectively referred to as background conditions, which are not always adequately considered prior to selecting a suitable management system. We examine the ability of one background condition, geologic terrane, to explain crude spatial variation in a number of trailing indicators of varying forest land use. Forest areas on Precambrian and Phanerozoic terranes show significant differences in production of fossil hydrocarbons, gold, and tropical roundwood, among other indicators, even after considering regional effects. Background conditions are considered to be factors capable of quantifying spatial variation in the likelihood of achieving management success given predefined benchmarks of sustainability. A number of avenues for further exploring and discriminating spatial variation of background conditions are discussed.
\end{abstract}

Key Words: enabling conditions; tropical forest management; geologic terrane; climate; sustainable development

\section{INTRODUCTION}

Improving prosperity among the poorest people and curtailing widespread environmental degradation are arguably the greatest challenges of the 21st century. A large fraction of both the world's poorest and global biodiversity are found in countries that house significant areas of tropical forest, many of which are under heavy or growing pressure to deliver tangible economic benefits. Thus, decisions regarding the future of tropical forests are paramount in efforts to direct broader economic development along a path that can assist in nearterm poverty alleviation while maintaining longerterm social and environmental sustainability. In some instances, forest conversion may prove an effective route to stimulating economic development (Wunder 2001), as in selected cases of oil palm, teak, or rubber plantations in southeast Asia or coffee plantations throughout Central America. In these cases, nonforest land uses have proven capable of leveraging forward momentum when decisions to alter the landscape were: (1) based on sound macroeconomic policies; (2) well managed; (3) delivering some, even modest, measure of equitability among direct stakeholders; and (4) following Hartwick's Rule (Hartwick 1977), generating savings that were ultimately reinvested to diversify national economic sector strengths and grow new employment and income. In the majority of instances in which achieving these conditions has proven more challenging, retaining existing tropical forest cover is more likely to be optimal. Intact forests can provision crucial subsistence services such as fisheries support and cash-income to local communities (e.g., Chao and Prang 1997), timber and nontimber receipts to national governments (Kremen et al. 2000), wage-earning opportunities, as well as more complex international public goods (IPGs) (Inge et al. 1999), through their integral role in global processes such as carbon and freshwater cycling, and as the world's largest biodiversity stores. Prospects for alleviating poverty and maintaining environmental value can decline precipitously with broad-based deforestation when it does not leverage significant development in other economic sectors. Thus, choices based on an inadequate understanding of the factors catalyzing 
and sustaining long-term prosperity and their relationship with forests in these countries can lead to accrual of nontrivial costs at various social scales. Without reinvestment of proceeds from forestland use, the link between the generation of short-term economic benefits and development of longer-term sustainability is decoupled, spiraling forest-based economies through a never-ending sequence of "boom and bust" commodity cycling that brings little prosperity to the poorest, transferring any value of future use options to external accounts and diminishing forests' functional roles in maintaining positive IPG accounts (e.g., Bunker 1985, Homma 1992, Barham and Coomes 1996, Bojanic 2001, Hammond 2005c).

Under pressure as both a source of economic wealth and contribution to national development, intact tropical forests have continued to decline in both distribution (Buschbacher 1986, Achard et al. 2002) and contiguity (Laurance and Bierregaard 1997, Asner et al. 2005), despite efforts to highlight the broad, and expanding, range of goods and services they offer (Barbier 1991). The factors put forward to explain this persistent contraction and fragmentation are varied, numerous, and shifting (Lambin et al. 2001, Rudel 2005). Efforts to curtail the rapid pace of tropical deforestation have largely focused on protecting areas and searching for integrated approaches and practices that can make using resources nondepletive and more equitable. Choices regarding which path to take have not occurred without constructive debate regarding the feasibility of managing commercial use of forests on a sustainable basis (Dickinson et al. 1996, Putz et al. 2001, Rice et al. 2001, Pearce et al. 2003, Zarin et al. 2004), or the role that traditional notions of protected areas can realistically play in delivering benefits and improving livelihoods (Sunderlin et al. 2005).

Proponents of sustainable forest management systems argue that intact forests can be managed in a way to ensure that exploited resources are replaced while retaining many other ancillary benefits that would be otherwise lost when forest cover is completely removed (de Graaf 1986, Barreto et al. 1988, Buschbacher 1990, Dickinson et al. 1996, Boltz et al. 2003, Zarin et al. 2004). At the core of these systems is a set of universal natural resource management principles that emphasize a careful balance between the extent and frequency of use and the rate of post-use recovery, i.e., growth into commercially harvestable size classes for offtake models (Freese 1998). However, more than not, systems designed to deliver sustainability at industrial scales of production have either not been fully implemented and/or have proven to fall short of required growth and yield projections (de Graaf et al. 1999), a situation that has also proven true for many other biological off-take models (e.g., Natural Research Council 1996, Frank et al. 2005). This is not to say that these systems have not been well engineered or capable of improving short-term forest management. Rather, delivery systems focused on single goods or services appear increasingly incapable of reaching sustainability benchmarks because these have over time:

1. expanded to address the more complex interrelationships shaping the way that capital is formed, flows, and is distributed across various scales (Repetto and Gillis 1988, Barbier et al. 1994, Kremen et al. 2000, Pearce and Pearce 2001, Fig. 1).

2. proven to be subject to more complex variation in background conditions that can strongly affect yield projection, harvestable stocking rate, and conversion rate accuracies (Peña and Zuidema 1999, Fang et al. 2001, Graham et al. 2003, Nemani et al. 2003, Peres et al. 2003). Variation in tropical forest productivity can be highly sensitive to overarching controls even in unmodified natural forest stands (Phillips et al. 1998, Baker et al. 2003, Graham et al. 2003, Nemani et al. 2003), and how these interact with the type and frequency of silvicultural interventions remains poorly integrated in traditional offtake models.

3. been based on management interventions, e. g., enrichment planting, post-harvest liberation, that have not always proven cost effective (s. 1.) once implemented due to conditions presented in (1) and (2) (King 1965, Chai and Udarbe 1977, Hammond et al. 2000).

4. remained relatively insensitive to external conditions varying uncertainty and risk attached to different tropical forests areas. Uncertainty dampens investor confidence, limits planning horizons, and increases risk (Sharpe et al. 1998). Insecure forestland tenure (Vincent and Gillis 1998, Godoy et al. 2001), poorly-resolved usufruct rights, 
Fig. 1. Schematic depicting basic interrelationships between physical, biological, social, economic, and cultural systems that operate to influence forest management at different scales. Arrowhead size indicates relative measure of influence on forests.

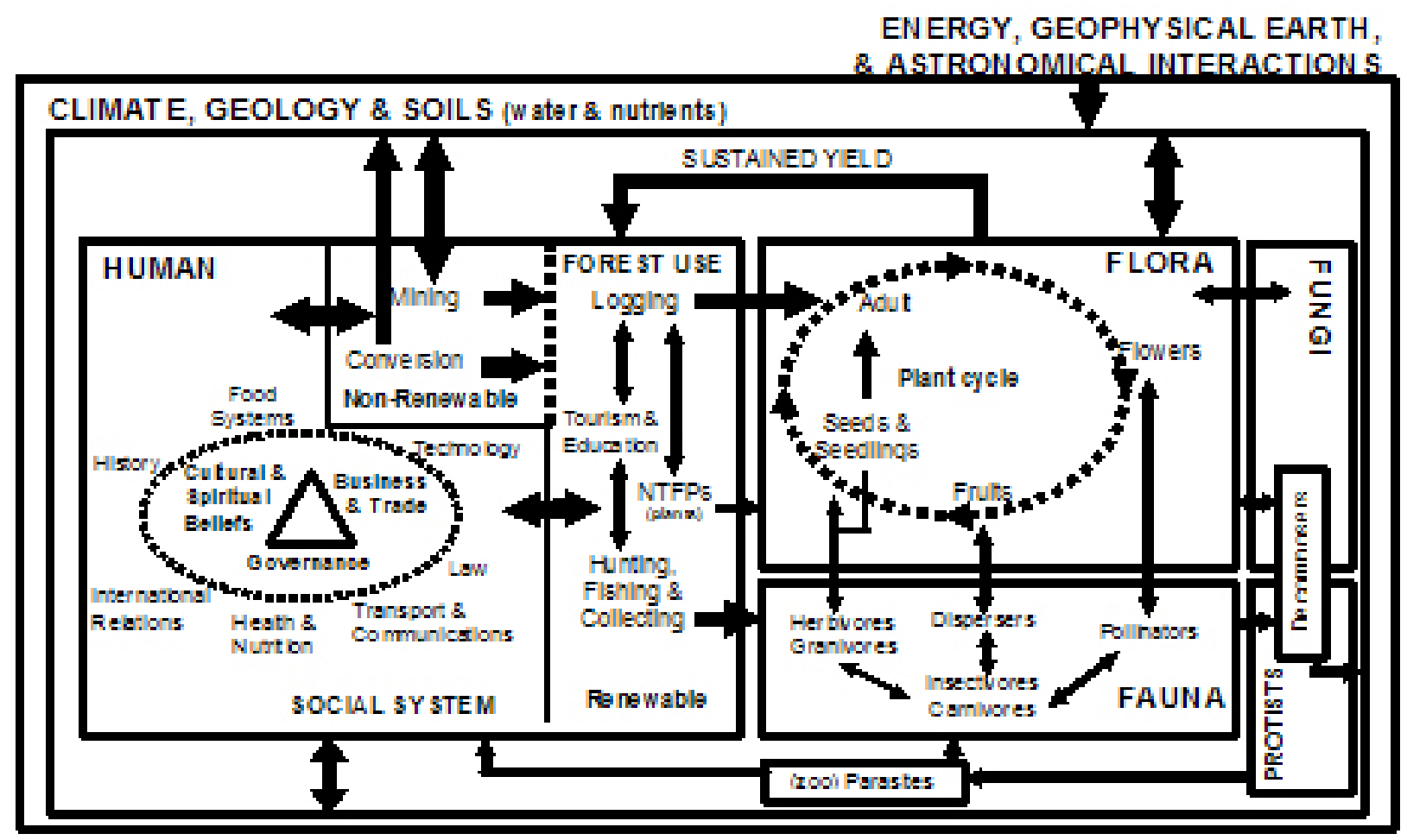

Reproduced with permission from Hammond (2005a). Tropical Forests of the Guiana Shield.

structured public subsidies (Repetto and Gillis 1988), poor rent capture (Vincent 1990), overlapping and incompatible forest resource use (Hammond $2005 b$ ), changes in the opportunity costs of labor, and prohibitive discount rates can create conditions fostering short-term capital depletion and flight instead of the capital growth and maintenance needed to leverage opportunities for managing toward sustainability. Many benchmarks simply fail to adequately account for shortterm financial decision making commonly carried out in the face of changing commodity market prices. Under unfavorable market conditions, ancillary management costs are often the first to be cut.
Combined, these factor groups can conspire to limit the broad-based applicability of resource management frameworks. This is particularly the case when they are designed to support sustainability in industrial-scale use of natural forest wood and nonwood products. Levels of capital required to maintain a net positive benefit flow are considerably greater in industrial-scale management than those required in subsistence-based models, such as field-fallow or extractive reserve systems. In forestry, the inverse relationship between cost effectiveness of reduced-impact logging (RIL) measures and harvest intensity in Indonesian forests exemplifies the sensitivity of net benefit flows to factors shaping operational outcomes (Sist et al. 1998). The potential carbon offset benefits of using RIL to reduce canopy cover loss in these forests (Pinard and Putz 1993) and the contrasting need to increase canopy openness to generate carbon offset 
Table 1. Some examples of poorly integrated extrinsic and intrinsic background conditions grouped by their influence on the relationship between management objectives and outcomes. Conditions are not necessarily independent. CCU stands for commercial consumptive use (sensu Freese 1998), RHT for resource and habitat taboos (sensu Colding and Folke 2001), and TEK for traditional ecological knowledge.

\section{Extrinsic}

\section{Spiking catastrophes}

Earthquake location, magnitude, and frequency

Spatial variation in volcanic activity and behavior

Trends in cyclonic activity

Extent and frequency of flooding

Depth and frequency of drought

\section{Primarily landscape legacies}

Age of geologic terrane

Type, distribution, and grade of subsurface resources

Type, duration, and extent of forest-use history

Hydrological processes and water quality

\section{Intrinsic}

\section{Spiking catastrophes}

Frequency and extent of violent conflict

Frequency and magnitude of famine

\section{Swelling transitions}

Fire susceptibility

Disease transmission rates and extent

CCU species decline

Non-CCU biodiversity decline

Accelerated greenhouse warming

\section{Relevant examples and case studies}

Garwood et al. 1979

Hammond 2005d

Webb 1958, Wadsworth 1959, Whitmore 1974, Nelson et al. 1994, Snook 1996

Salo et al. 1986, Hammond 2005d

Salafsky 1994, Glantz 1998

Hammond 2005d

Miranda et al. 1998, Peterson and Heemskerk 2001, Hilson 2002, Hammond 2005c

Dargavel et al. 1988, Homma 1992, Coomes 1995, Barham and Coomes 1996, van Gemerden et al. 2003, Hammond 2005c

Degens 1982, Milliman and Meade 1983, Marengo 1995, Aalto et al. 2003

Draulans and van Krunkelsven 2002, Dudley et al. 2002, McNeely 2003, Price 2003

Currey and Hugo 1984

Fearnside 1990, Kauffman and Uhl 1990, Hammond and Ter Steege 1998, Murty et al. 2000, Siegert et al. 2001

Patz et al. 2004, Karesh et al. 2005

Peña and Zuidema 1999, Bennett and Gumal 2001, Fimbel et al. 2001, Peres et al. 2003

Laurance and Bierregaard 1997

Brown et al. 1993, Condit et al. 1996, Nemani et al. 2003 
Invasive species distribution and density

\section{Primarily social legacies}

Education and training quality and opportunity

Skilled labour migration

Political system structures and platforms

RHTs and TEK retention

Corruption

\section{Primarily economic legacies}

Monetary policies

Global trade structures and conditions

Land use policies

Land tenure

Enforcement \& monitoring capability
Sheil 1994, Cochrane and Schulze 1999, Fine 2002

Hammond et al. 2000

Adams 2003, Özden and Schiff 2006

Fearnside and Barbosa 1996

Berkes et al. 2000, Colding and Folke 2001

Robbins 2000

Eichengreen and Kenen 1994

Barbier et al. 1994

Hecht 1985, Repetto and Gillis 1988, Cockburn et al. 1999, Lambin et al. 2001, Rudel 2005

Godoy et al. 2001

Rodan et al. 1992, Smith 2002, Karsenty 2003 benefits in Guyanese forests (ter Steege 1998) illustrates how biophysical variation can test pantropical applicability of management models and benefits of their application (Hammond et al. 2000).

Identifying factors prospectively limiting management performance can assist in better aligning benchmarks, prescriptions, and expected benefits. Background conditions, in particular, represent an important pool of these factors since they, unlike operational conditions, may not be addressed directly in frameworks or as easily through "adaptive" approaches, but can work both surreptitiously and assiduously against progress even when management frameworks are well implemented. The spread of fire as a function of the spatial distribution of forest land use activities and the downstream air quality impacts on urban centres during warm El Niño-Southern Oscillation (ENSO) phases in Amazonia and Indonesia (Kauffman and Uhl 1990, Hammond and ter Steege 1998, Cochrane and Schulze 1999, Murty et al. 2000, Siegert et al. 2001) and arsenic poisoning of groundwater wells in Bangladesh and West Bengal, India (Nickson et al. 1998) provides lucid examples of the massive social and environmental costs that can accrue from a poor understanding of background conditions, how these vary, and the way that they can interact with resource management objectives to deliver unexpected consequences. Variation in background conditions can also influence capacities for uptake of management improvements. The selective capacity among developing countries in their uptake of green revolution technologies highlights how varying background conditions can lead to different outcomes, even when management systems and technologies are proven equally capable of delivering benefits (Barbier and Conway 1990).

\section{Background conditions and forest management}

Background conditions are often perceived as a pool of common knowledge and thus may not always be explicitly recognized in systems aiming to manage forests sustainably at different scales. They regulate at large scales the capital flows needed to maintain productivity in the system and thus can create drags on progress toward sustainable development goals when established benchmarks are misaligned with overarching controls. In the worst case, ensuing 
Fig. 2. Tropical closed broadleaved forests and the distribution of these occurring on Phanerozoic (green) and exposed Precambrian terranes (brown) in South and Central America, Africa, and AsiaOceania prior to losses accrued through modern deforestation. See Methods for details of coverages.
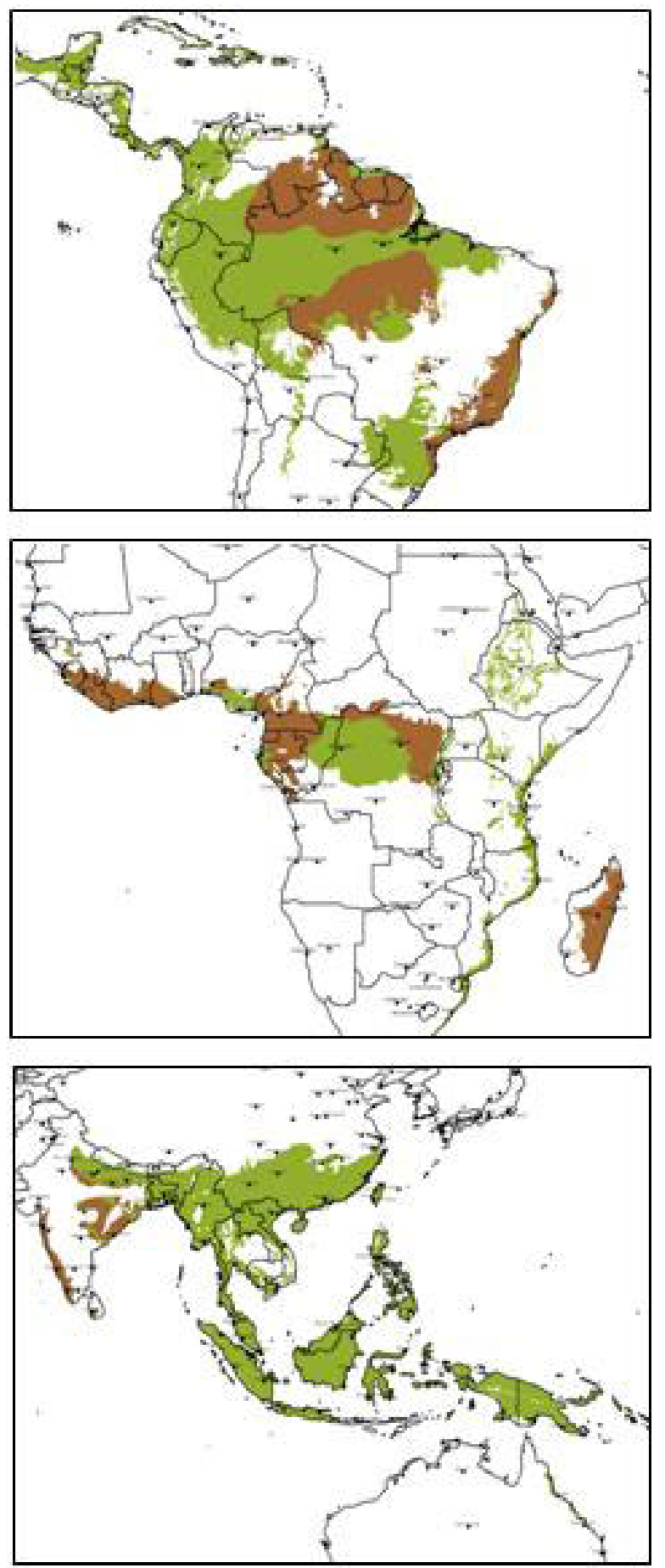
Table 2. Major global tropical forest areas by country and according to predominant age of underlying geology. Precambrian provinces assigned to forest area in each country given in left column (sensu Goodwin 1996). NFA stands for estimated percentage of national tropical broadleaved forestland area atop Precambrian terranes. See Methods for further coverage details. ARAB-NUB: Arabian-Nubian Shield, BAN: Bhandara Craton, BE-NI: Benin-Nigeria Shield, BS: Brasilian Shield, CAM: Cameroon Shield, CH: Chaillu massif, DHWR: Dharwar Craton, FR: Francevillian Supergroup, GAB: Gabon Shield, GS: Guiana Shield, HIWAN-VIJ: Highland Group, Wanni Complex-Vijayan Complex, KAS: Kasai Angolan Craton, KAT: Katangan Belt, KIB: Kibarides Belt, MAN: Man Shield, MAD: Madagascar Shield, and WC: West Congo.

\begin{tabular}{|c|c|c|c|c|c|}
\hline & $\begin{array}{l}\text { Primarily Precambrian } \\
\text { (> 550 my BP) }\end{array}$ & NFA \% & & $\begin{array}{l}\text { Primarily Phanerozoic } \\
\text { (< } 550 \text { my BP) }\end{array}$ & NFA \% \\
\hline \multicolumn{6}{|l|}{ Africa } \\
\hline KAT & Burundi & 94 & BE-NI & Benin & 43 \\
\hline CAM & Cameroon & 95 & & Comoros & \\
\hline CAM & CAR & 57 & WC-CH & DRC (NE) & 1 \\
\hline MAN & Cote d'Ivoire & 96 & CAM & DRC (North) & 37 \\
\hline GAB-CAM & Equatorial Guinea & 94 & BE-NI & Nigeria & 39 \\
\hline GAB-FR-CH & Gabon & 82 & WC-CH-FR-CAM & Republic of Congo & 33 \\
\hline MAN & Ghana & 90 & & & \\
\hline MAN & Guinea & 84 & & & \\
\hline MAN & Liberia & 99 & & & \\
\hline MAD & Madagascar & 97 & & & \\
\hline KIB & Rwanda & 92 & & & \\
\hline MAN & Sierra Leone & 73 & & & \\
\hline BE-NI & Togo & 95 & & & \\
\hline KIBI & Uganda & 100 & & & \\
\hline \multicolumn{6}{|l|}{ Asia-Oceania } \\
\hline ARAB-NUB & Seychelles & 100 & & Bangladesh & \\
\hline \multirow[t]{8}{*}{ HI-WAN-VIJ } & Sri Lanka & 100 & & Brunei Darussalam & \\
\hline & & & & Cambodia & \\
\hline & & & BAN & India & 33 \\
\hline & & & DHWR & India & 9 \\
\hline & & & & Indonesia & \\
\hline & & & & Laos & \\
\hline & & & & Malaysia & \\
\hline & & & & Mauritius & \\
\hline
\end{tabular}




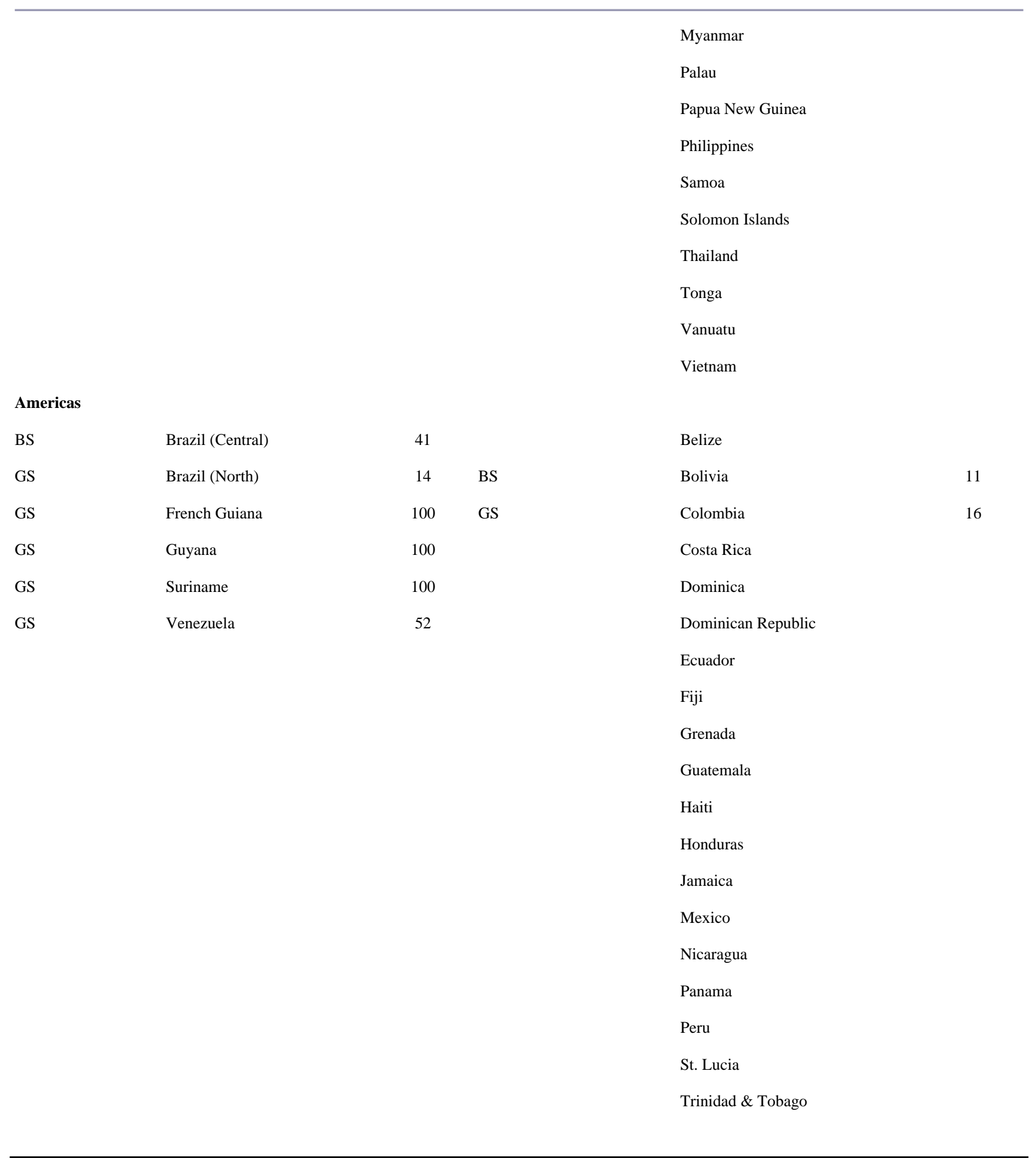


Fig. 3. A cross section of production and development indicators averaged across tropical forest countries as listed in Table 2 and according to dominance by Precambrian (PC) and Phanerozoic (PH) terranes. In the case of Brazil, state-municipio values were assigned based on overlap with PC or PH geological province. Data sources: FAO 2004, INEGI 2004, USGS 2004, World Bank 2005. Error bars represent standard errors. Filled bars in Forest Area and GNI averages for PH countries depict averages with Pacific and Caribbean islands removed.
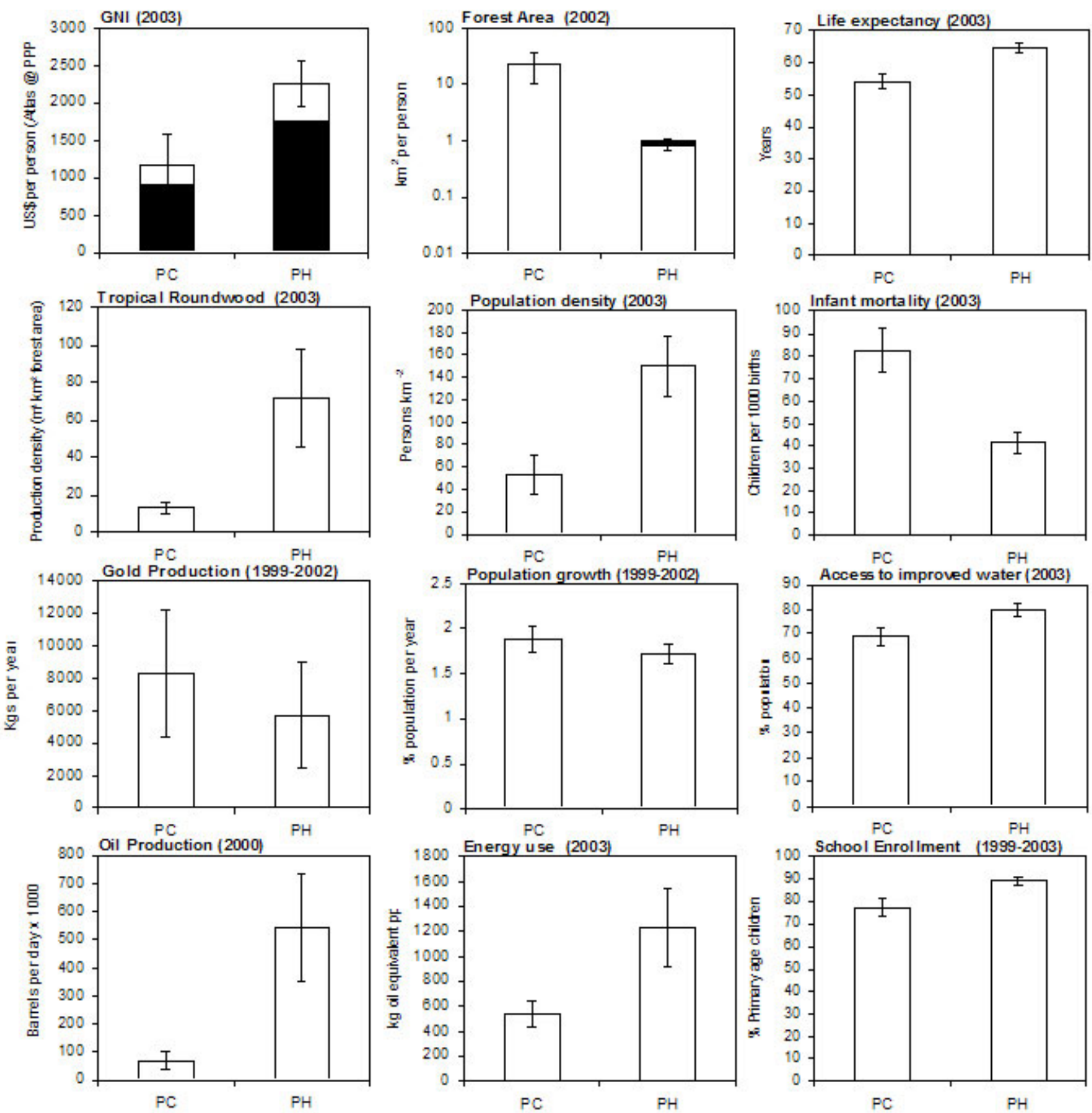
Fig. 4. Relationship between geology and (A) Tropical roundwood production density and (B) Population density as seen when drilling down along a Neotropical pathway. Note log axes.
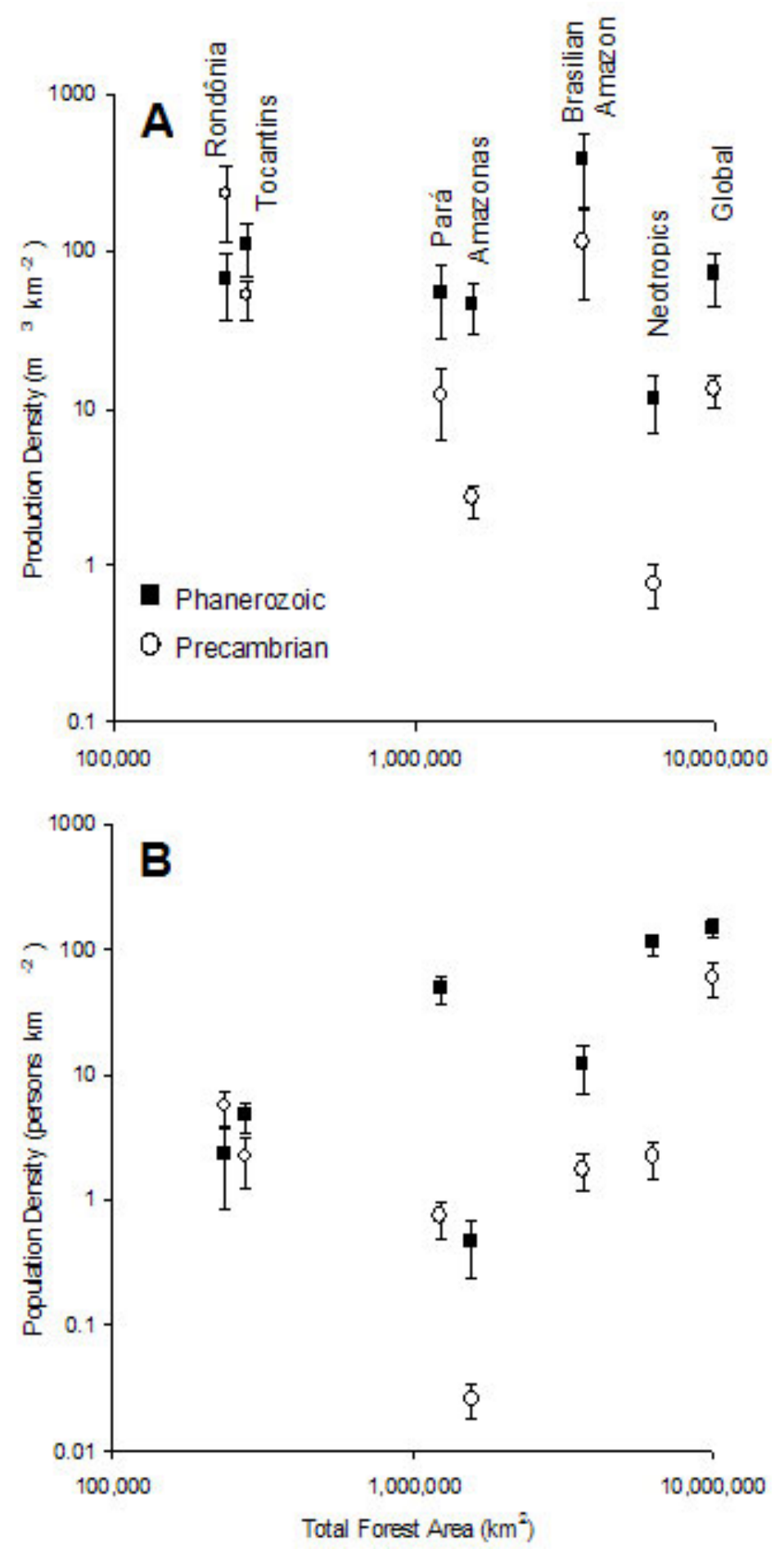
Table 3. Selection of transformed socioeconomic indicators run through a series of generalized linear models to assess the role of geology, i.e., precambrian vs. phanerozoic, and geographic region, i.e., Neotropics, Africa, Asia, and Oceania, in explaining pantropical variation.

\begin{tabular}{llllll}
\hline \hline Indicator & Variable & $R^{2}$ & df & $F$ & $P$ \\
\hline Tropical Closed Broadleaved Forest Area & Geology & 0.18 & 1,68 & 15.27 & $<0.001$ \\
$\left(\mathrm{~km}^{2} /\right.$ person) & Continent & 0.06 & 3,66 & 1.39 & $>0.050$ \\
& Geology after Continent & 0.17 & 1,68 & 14.16 & $<0.001$ \\
Income, Debt, and Investment & & & & & \\
GNI (US\$/person, Atlas method @ PPP) & Geology & 0.07 & 1,66 & 5.17 & $<0.010$ \\
& Continent & 0.5 & 3,62 & 21.13 & $<0.001$ \\
& Geology after Continent & $<0.01$ & 1,64 & 0.19 & $>0.050$ \\
& Continent after Geology & 0.37 & 3,62 & 11.91 & $<0.001$ \\
Total Government Debt (US\$ @ PPP) & Geology & & & & $>0.050$ \\
Direct Foreign Investment (US\$) & Geology & $<0.01$ & 1,59 & 0.233 & $>0.050$
\end{tabular}

\section{Population \& Health}

\begin{tabular}{|c|c|c|c|c|c|}
\hline \multirow[t]{2}{*}{ Population Growth (\% previous population) } & Geology & $<0.01$ & 1,61 & 0.57 & $>0.050$ \\
\hline & Continent & 0.25 & 3,59 & 6.43 & $<0.001$ \\
\hline \multirow[t]{4}{*}{ Population Density (persons/km²) } & Geology & 0.24 & 1,70 & 22.24 & $<0.001$ \\
\hline & Continent & 0.15 & 3,68 & 4.28 & $<0.010$ \\
\hline & Geology after Continent & 0.24 & 1,70 & 23.38 & $<0.001$ \\
\hline & Continent after Geology & 0.22 & 3,68 & 6.56 & $<0.001$ \\
\hline \multirow[t]{4}{*}{ Life Expectancy (yr) } & Geology & 0.14 & 1,62 & 9.64 & $<0.010$ \\
\hline & Continent & 0.74 & 3,60 & 56.53 & $<0.001$ \\
\hline & Geology after Continent & $<0.01$ & 1,62 & 0.39 & $>0.050$ \\
\hline & Continent after Geology & & & & \\
\hline \multirow[t]{2}{*}{ Infant Mortality (children/1000 births) } & Geology & 0.16 & 1,62 & 11.82 & $<0.001$ \\
\hline & Continent & 0.57 & 3,60 & 26.73 & $<0.001$ \\
\hline
\end{tabular}


Geology after Continent

Continent after Geology

Access to Improved Water (\% population)

\author{
Geology \\ Continent \\ Geology after Continent \\ Continent after Geology
}

$<0.01$

1,62

0.05

$>0.050$

\section{Education}

Primary School Enrollment (\%)

\author{
Geology \\ Continent \\ Geology after Continent \\ Continent after Geology
}

$\begin{array}{llll}0.16 & 1,49 & 9.49 & <0.010 \\ 0.61 & 3,47 & 24.3 & <0.001 \\ <0.01 & 1,49 & 0.46 & >0.050 \\ 0.36 & 3,47 & 8.65 & <0.001\end{array}$

\section{Commodity Production \& Energy}

Tropical roundwood production $\left(\mathrm{m}^{3} \mathrm{~km}^{-2}\right.$ forest Geology area)

Continent

$\begin{array}{llll}0.08 & 1,46 & 3.78 & <0.050 \\ 0.04 & 3,44 & 0.65 & >0.050\end{array}$

Oil Production (barrels/d)

Geology

Continent

0.1

0.13

1,51

5.35

$<0.050$

Gold Production (kg/yr)

Geology

Continent

0.09

0.02

3,39

2.34

$>0.050$

Energy Use (kg oil equivalent/person)

Geology

Continent

0.07

0.14
1,66

3,65

6.29

$<0.050$

$0.37>0.050$

1,35

2,35

$$
2.7>0.050
$$$$
2.78>0.050
$$

leakages fundamentally derail progress towards initial benchmarks as natural, human, financial, and social capital growth cannot be sustained, and investment in management necessarily declines. A number of key background conditions and the way that they might influence sustainable management system success are briefly described in Table 1 .

These can be categorized into two groups. The first group consists of "extrinsic" background conditions
(Table 1). Geological landforms, climate oscillators, characteristics of native plant and animal communities, and past human use patterns, among other factors, calibrate how tropical forests can be expected to respond to different management applications (Fig. 1). Since these conditions are not distributed uniformly throughout modern tropical forest regions, and we cannot actively manage the influence they have already imparted, we cannot expect standing forests to respond in the same way 
to a standard set of forest use and conservation practices (Hammond 2005d, Primack and Corlett 2005, Rudel 2005), even if these are generally adapted to tropical environments. These conditions "limit" the spatial applicability of management practices when benchmarks are held constant. Modern management prescriptions rarely account for these explicitly, choosing instead to focus on near-term actions that will lead to sustainability in the future. Extrinsic background conditions can consequently derail progress toward management benchmarks if initial prescriptions have not adequately accounted for their effects.

The second group consists of "intrinsic" background factors that can alter prospects for sustainable forest management, but are strongly linked to a broader set of interconnected compartments influencing sustainable human development (Fig. 1). In effect, they "enable, frameworks to be implemented (Sheil et al. 2004, Sunderlin et al. 2005). Social conditions linked to education, health care, wealth distribution, political stability, skilled-worker migration (Özden and Schiff 2006), formal and informal private economic sector strength, cultural and social customs, and legal system functioning, among others, weigh heavily on prospects for success in implementing complex sustainable forest management systems. The choice of business models to be used, e.g., product quantity vs. quality, (Hammond $2005 b$; D. S. Hammond, personal observation), how forests are stewarded, e.g., public vs. private ownership (Repetto and Gillis 1988), and other microeconomic factors also interact to shape how sustainability might best be achieved, as do the distribution and magnitude of competing forestland uses such as mining, and the factors that propel each of these relative to other options (Hammond 2005b). Tropical forest countries are not challenged to the same degree by these conditions nor are they uniform in their capacity to overcome these challenges. Management models often do not consider the limiting effects, and added costs, that intrinsic background conditions can play on the realistic prospects for implementing sustainable management strategies and practices, such as RIL, outside the research plot environment (Hammond et al. 2000). Even the long-term implementation of highly controlled demonstrations can fall short when intrinsic background conditions such as political or economic crises, e.g., rebellion in Suriname, (de Graaf 1986), or a change in public sentiment, e.g., protection vs. use of Australia's rainforests, or market demand, e.g. through substitution, specifically alter much broader assumptions adopted during framework development.

These questions, thus, ask whether a focus on similarities or differences is most important in assessing how best to manage toward sustainable use over any particular forest area and whether a bottom-up or top-down approach to defining sustainability is most appropriate. If geographic differences in background conditions are considerable, then the risk of applying a more generic framework may be greater than anticipated. Conversely, if conditions prove more uniform, then local tailoring could be overconservative, quelling capital inflows by overcomplicating prescriptions aimed at addressing background conditions.

A number of background conditions could classify as good stratifying factors (see Table 1), but geology is of particular interest to us because the spatial distribution of underlying cratonic features and its influence on forest ecosystems remains largely beyond human control. As a major extrinsic background condition it can shape the relative impact of both spiking, i.e., high amplitude, short wavelength, smaller area, and swelling, i.e., lower amplitude, longer wavelength, larger area, catastrophes on management as well as shape spatial changes in biophysical, or landscape, legacy effects (Table 1). Thus, they may inherently affect a cascade of biophysical and social linkages underpinning forest management applicability at a wide range of scales (Fig. 1).

\section{Macrogeology as a background condition}

Tropical closed forests on Precambrian terranes cover an estimated $5 \times 10^{6} \mathrm{~km}^{2}$ in 28 countries (Hammond 2005a) and occupy large portions of the Amazon, Essequibo, Congo, Niger, Orinoco, and Volta Basins, as well as Madagascar, India, Sri Lanka, and the Seychelles (Fig. 2). The relative rarity of tropical forests on Precambrian terranes in southeast Asia and throughout Oceania (but see Goodwin 1996 for minor exceptions) strongly contrasts with continental areas of South America, Africa, and India (Fig. 2, Table 1). Around 6 X $10^{6}$ $\mathrm{km}^{2}$ of tropical forest on Phanerozoic terranes can be found dispersed among 53 countries (Table 2). Seven of these countries have significant portions of their tropical forest on both Precambrian and Phanerozoic terranes (NFA $=25-75 \%$ in Table 2 ). 


\section{Precambrian vs. Phanerozoic in the Neotropics}

Across the Neotropics, the effect of this distinction resonates through edaphic, hydrological, biological, and social systems. A wide range of biogeochemical data generally supports a view that forests on Precambrian terranes are diverging from neighboring lowland Phanerozoic regions that are considerably younger and continue to receive external nutrient and moisture reservoirs through their linkages with tectonically-active highlands (Hammond 2005d,e). In contrast, Precambrian shield regions lack the elevational gain necessary to generate significant snow and ice fields and the exposed mineral surfaces that act as important import sources for lowland environments.

Prehistoric and historic patterns of colonization and commercial forest use around the Guiana Shield also show a strong predilection towards build up along the Phanerozoic margins. This may be tied to the acute tropical acidity achieved in areas dominated by exposed Precambrian rock relative to comparable Phanerozoic regions, the need to maintain links with heightened aquatic productivity of larger rivers and coastlines and/or the difficulty of river-based access in comparison to waterways running through the deep sedimentary cover of the Amazon Trough and Sub-Andean Foredeep regions and along coastlines (Hammond 2005c).

If these contrasting tropical environments are linked to their duration and type of weathering regimes, then biological indicators should conform to this distinction. Although evidence is far from conclusive, some plant attributes such as wood density (Whitmore and da Silva 1990, ter Steege and Hammond 2001, Verburg et al. 2003, Hammond 2005e), seed size (Hammond and Brown 1995, Boot 1996, Hammond 2005e), and photosynthetic compensation (Pons et al. 2005) generally indicate that forests on the Guiana Shield favor plant taxa contrasting in their physiological and morphological adaptations with those on other Phanerozoic terranes. Whether this reflects adaptive radiation effects related to the much longer existence of Precambrian terrestrial environments (Ek 1997, Chanderballi et al. 2001, Hammond $2005 e$ ) or response to selective pressures driven by the dynamism attached to underlying geological age and/or climatological variation remains unclear.

Regardless, landscape-scale differences in the way forests accumulate taxa and biomass in the tropics and how these maintain their populations is critical to the long-term sustainability of forest use in these regions. Plant attributes directly interact with practices through efforts to manage growth, i.e. physiological responses, recruitment, i.e., fecundity, dispersal, and juvenile survivorship, and physical, morphological and chemical properties, i.e., density, shape, form, among others. In turn, these reflect long-standing selective pressures that may not be consonant with the economic objectives of management models profitably applied elsewhere. This is a nontrivial consideration in viewing sustainable development options, since the role that forests play in delivering benefits rest first with their basic ability to provision biogeochemical resources and then with how these are most effectively managed by society.

\section{METHODS}

To examine this potential effect, the global tropical forest estate was first defined using tables and appendices drawn from FAO's Global Forest Resources Assessment (FAO 2004) and spatially characterized using an annealed coverage derived from tropical moist, wet, rain, and montane ecoregions forming part of WWF's terrestrial ecoregion analyses (Olson et al. 2001). These are collectively referred to here as tropical closed broadleaved forests. A pantropical geological coverage was developed by categorizing underlying macrostructures as Precambrian (> 550 my BP) or Phanerozoic (< 550 my $\mathrm{BP})$ regions based on USGS's WPA coverage (Osmonson et al. 2000). It is important to note that near-surface subsoil ages of Phanerozoic coverage beneath tropical forest areas is relatively deficient through the Paleozoic (550-220 my BP) and Mesozoic (220-70 my BP) with most modern province features thought to be related to diastrophic and sedimentary processes in the Cenozoic ( $<70$ my BP). See Hammond (2005a) for further details of coverage development and calculations.

To explore the broad socioeconomic implications of living and working with tropical forests on contrasting geological terrines, we extracted, when available, a cross-section of data from the World Bank (2004), FAO (2003, 2004), USGS (2004), and the Comisión Económica para Americana Latina (CEPAL) for the 70 countries identified above as having closed tropical broadleaved forest cover. These data covered a wide range of forest area, 
population, production, e.g., sawn and plywood, oil, and gold, health, e.g., infant mortality, life expectancy, access to improved water, macroeconomic, e.g., gross national income (GNI) per capita, foreign debt, foreign investment, and microeconomic, i.e., energy use per capita, statistics that were used to explore whether background conditions linked to the $\mathrm{PH} / \mathrm{PC}$ dichotomy cut across different components normally attached to broad measures of sustainability. Figures for countries with significant forest areas on both terranes (see Table 2) were allocated based on spatially refined national statistical data or spatial coverage that allowed credible distinctions to be made, e.g., for Brazil through the Instituto Brasileiro de Geografia $e$ Estatística (IBGE 2004). Individual countries were adopted as sampling points since policies and practices are more likely to be adopted uniformly at the national level than any other scale, particularly when the lion's share of forest area is publicly owned. Australia was excluded from the dataset used here, since socioeconomic attributes identified it as a strong statistical outlier in relation to other countries with tropical forest.

\section{Pantropical and continental scales}

At the pantropical scale, we examined differences in development and forest-sector indicator averages for PH and PC countries using general linear models (GLM) (Systat 1998). Dependent variable datasets were transformed using the Box-Cox approach when not meeting assumptions required for parametric analysis (Kirby 1993). To examine whether any statistically significant differences were leveraged by disproportionate regional effects, we applied GLMs in a stepwise fashion using geology (two levels, PC vs. PH) and then region (four levels, South/Central America and Caribbean, Africa, South and Southeast Asia, Oceania) to explore how much of variation explained by geology could be accountable to region. We also removed small island states to compare their effect on averages and whether they contributed disproportionately to differences since all islands except the Seychelles are of Phanerozoic age and may constitute a separate population from continent-based countries due to their insularity and the unique effect this condition may have on socioeconomic and biophysical change.

\section{National scale: case of Brazil}

At the national scale, we again examined differences as above but only for states containing tropical forest in Brazil. Brazil was selected due to its large forest area distributed across both $\mathrm{PH}$ and $\mathrm{PC}$ terranes and the unparalleled data available for many development and forest-sector indicators at state and substate, i.e., municipio spatial scales. Brazilian states and municipios were categorized based on overlap with tropical closed broadleaved forest and geological spatial coverage. Averages for the period 1999-2003 were calculated using the municipio as a sampling point. Exploring how geology figures in stratifying socioeconomic conditions is more difficult for tropical forest countries in Africa and Asia. Phanerozoic terranes dominate forested regions in most countries in Africa and virtually all in Asia (Fig. 2). Where both PH and PC terranes exist within a country, e.g. Democratic Republic of Congo, adequately portioning values according to geological terrane is more difficult due to the lack, or availability, of the detailed data necessary to explore transitions across smaller spatial scales.

\section{RESULTS}

\section{Geologic terrane as an extrinsic background condition}

Of the 14 social and economic indicators analyzed for the basket of 70 tropical forest countries, most showed distinct differences when categorizing by the predominant underlying geological age (Fig. 3). Gross National income for inhabitants of countries with tropical forest primarily atop Precambrian (PC) geology was on average nearly half the income generated by people living in countries with tropical forest on Phanerozoic (PH) terranes. The average forest area for each inhabitant of $\mathrm{PH}$ countries is, however, a mere $4 \%$ of the area found in PC countries for each inhabitant (Fig. 4). This is related to both a larger average forest estate in PC vs. PH countries, i.e., $189,257 \mathrm{~km}^{2}$ vs. $142,906 \mathrm{~km}^{2}$, and considerably lower population densities (Fig. 3). Factors influencing population density are also, on average, influenced by the age of the geological terrane. Mortality among newborn children in $\mathrm{PH}$ countries is nearly half that of PC countries (Fig. 3). People in $\mathrm{PH}$ countries also live on average nearly $10 \mathrm{yr}$ longer than those in PC countries. However, population growth from 1999-2002 was slightly higher in PC than in $\mathrm{PH}$ countries. 
Oil extraction, gold mining, timber production, and agriculture are the four major commodity-based uses of tropical forestlands. Of the first three, both oil and tropical roundwood production are noticeably lower on average for $\mathrm{PC}$ vs. $\mathrm{PH}$ countries. Conversely, gold production is somewhat higher on Precambrian terranes (Fig. 3). At first glance, per capita energy used to drive industry and provide for residential living also appears lower in PC countries (Fig. 3).

However, the role of geological terrane in explaining these differences could be confounded by other variables. PH terrane covers virtually all of the tropical forest area in Asia and Oceania, particularly when compared to the much greater area of forest atop PC terranes in South America and Africa (Fig. 3). General linear models indicate that the role of geographic region can be equally or more important in explaining differences attached initially to geology (Table 3 ). This would not preclude a role of geology in driving social and environmental differences, but rather the geographic distribution of geology and its putative influences may define these at larger scales that cannot be easily separated to fit into testable models. Some specific variables such as per capita forest area and its correlate, population density, remained strongly attached to the distribution of $\mathrm{PC}$ and $\mathrm{PH}$ terrane even after considering geographic, i.e., continent effects (Table 3). A significant role of geographic region in explaining variation in tropical roundwood, oil and gold production could not be found (Table 3), although approximately $10 \%$ of variation could be significantly explained by association with tropical forest countries dominated by $\mathrm{PH}$ vs. PC terrane (Table 3 ).

How robust is this coarse pantropical effect of geology when considering smaller scales? Taking the case of tropical roundwood, geology generally appears to discriminate production levels. Consistently higher production levels from $\mathrm{PH}$ terranes in comparison to $\mathrm{PC}$ areas appear across a wide range of spatial scales and despite shifting magnitudes of production when drilling down along a Neotropical pathway (Figure 4A). A similar trend is found for 2003 population densities (Fig. 4B). This relationship begins to dissolve, however, when considering averages at the municipio-scale in two of the five Brazilian states containing tropical forest cover on both PC and PH terranes (Rondônia, Fig. $4 B)$.

\section{DISCUSSION}

Changes in background conditions, whether biophysical or socioeconomic, have often been stated as the leading cause of forest management failure (Chauvin 1976, Dawkins and Philip 1998). Understanding how these conditions vary provides a more dynamic, and robust, basis on which to assess what is necessary to both appraise and work towards sustainable use. In other words, characterizing these conditions can assist in establishing how risk, and thus anticipated return on investment, is likely to influence the outcomes of proposed forest management systems. In a competitive investment environment in which both public and private-sector capital can be scarce, yet remains imperative to development, characterizing the interplay between uncertainty and forest management is crucial if sustainability is to prove a realistic goal.

Land use assessment (LUA) is arguably the most prominent of the traditional tools used in determining how best to allocate forest area toward different land use objectives, including protection. This is often seen as an antecedent to planning methods generally tailored around the management of wood growth and extraction in timber production areas. In general LUA attempts to partition continuous changes in standing forestland resources based on a set of landscape characteristics (Carpenter 1981). Its heavy weighting on the state of the biophysical landscape at time of assessment, however, does not adequately address a number of other requirements that are now considered crucial to achieving broad sustainability, including:

1. the spatial variation in other key capital components of sustainability such as social, economic, human, i.e., labor, and political pools;

2. the variation in intrinsic, or enabling, background conditions that ultimately filter management success from failure;

3. a more dynamic categorization of spatial variation based on classifying background conditions by measures of dispersion, e.g. interannual variation in seasonal rainfall, rather than central tendency, e.g., average annual temperature and rainfall, slope, soil fertility. LUA fractionated forests into static suitability and capability classes based on 
average or cumulative counts, e.g., Holdridge life zones, land systems, rather than how these varied with time or with change in spatial scales; and

4. processes that create goods and services that are consumed in ways not typically valued through traditional management approaches, such as global or international public goods.

Whereas LUA techniques helped to organize coherent approaches to tropical forest use and form an important first-step in discriminating grossly incompatible land use activities, one might suggest that volatility in background conditions is a better indicator of the constraints that will challenge sustainability. Volatility in extrinsic and intrinsic background conditions reflects underlying forces that combine to shape forest change. Examining how volatility in background conditions varies spatially might fulfill the same purpose as LUA, $\mathrm{i}$. e., zoning allowable or optimal forestland use, but better account for processes driving forest change rather than describing standing conditions of forests at the time of sampling. This would provide a much better basis for assessing the risk-reward relationship that should be attached to adoption of most sustainable management systems that lack empirical verification of their long-term suitability.

\section{Tailoring management: case of geology}

The distinctions drawn here between tropical forest areas on Precambrian and Phanerozoic terranes illustrate how certain attributes that vary spatially, can condition the risk-reward attached to management system selection. The wide PC-PH gap in forest area available per inhabitant, population density, and major commodity production levels appears to supercede geographic effects posed by sectioning the global estate into four regions. Other socioeconomic factors such as GNI per capita, life expectancy, infant mortality, and primary school enrollment could be linked to geology, but the segregation of terranes at the regional scale may explain most of the resulting variation.

At first glance, a relationship between geology and socioeconomic indicators across a wide range of countries with tropical forest cover would seem counter-intuitive, if not spurious. However, there are fundamental distinctions between these terranes that might provide a plausible explanation for their broad-based segregating role as an extrinsic background condition. In the Neotropics, tropical forests ecosystems on Precambrian terranes are more acidic and less productive. Shield regions are isolated from the young, mechanically erosive surfaces of the regional mountain systems. With little atmospheric deposition, they represent highly closed nutrient systems and show some of the lowest standing nutrient levels in the region (Hammond $2005 d$ ). In contrast, hydrological connections with upland weathering surfaces buffer acidity and provide external nutrient transfers across many Phanerozoic regions (Hammond 2005e). Compounding this fact is the substantively greater period that most Precambrian surfaces have been subject to mechanical and chemical weathering in relation to much younger Phanerozoic surfaces across the Neotropics. These have strongly influenced the vertical and horizontal distribution of mineral resources, the global macroeconomic conditions needed for their profitable extraction, the type of extraction systems required and the breadth and duration of landscape impacts. There is some evidence to suggest that varying mineral exportation and deforestation rates are linked (Sunderlin and Wunder 2000, Wunder and Sunderlin 2004), but more work is needed to identify whether trends such as those described for mineral production would hold up across a wider range of PC-PH comparisons.

Extraction of standing wood resources also appears more limited in many forests atop Precambrian terranes. Some of the lowest values for standing biomass and tree species diversity are recorded from tropical forests on Precambrian terranes, even across similar rainfall regimes. A similar result appears true for aquatic productivity in rivers coursing these geologic regions. If these distinctly different geological life histories have influenced the course and content of biological adaptation, then we can expect that these divergent landscapes would logically yield different forest livelihood opportunities and constraints. Thus, it is probably not coincidental that both archaeological and ethnohistoric evidence currently points to more sophisticated societies accumulating along Phanerozoic margins of the Guiana Shield where opportunities for sustaining livelihoods have been more numerous and not fully dependent on the relatively modest productivity of interior forests (Hammond 2005c). 


\section{Conditional cross currents}

Although geology appears capable of defining natural limits to the type and trajectory of challenges that forest management approaches need to consider, it remains only one of many background conditions capable of weighting prospects for sustainability (see Table 1 for examples). Other factors clearly play an important role in driving many of the social conditions, e.g., health and education, which ultimately support or erode efforts to sustainably manage tropical forests, although this may not be strictly apparent at the forest management unit level. Two brief examples help to illustrate these effects and how they can interact to create contingencies to management system success.

Rapidly developing, or spiking catastrophes (Table 1) and a region's susceptibility to these can create conditions that alter public priorities and reshape perceptions about how best to manage forests over the long-term and what benefits to target, e.g., coastal protection against hurricanes/tsunamis vs. timber production. These cross-current effects can also be seen through spatial variation in ENSO precipitation anomalies, where eastern equatorial rims of Asia (Rasmusson and Wallace 1983), Africa (Anyamba et al. 2002), and South America (Enfield 1996) are susceptible to strong El Niño-induced drought events that are weak or absent from West Africa or western Amazonia (Ropelewski and Halpert 1987, Philander 1990, Dai and Wigley 2000). Drought not only intersects with management practices such as road design, ignition sources, logging intensity, and fuel loading (Siegert et al. 2001), but also through constraining impacts such as disease transmission (Gagnon et al. 2001, Gagnon et al. 2002), that inflate public health costs, limit skilled labor availability, and foster chronic poverty in rural environments. Forest of Central America, the Caribbean (Wadsworth 1959), the Solomon Islands (Whitmore 1974) and North Queensland, Australia (Webb 1958) are, among other areas, subject to hurricane or cyclone impacts, but South American and West African forests are virtually immune from such catastrophic events (Hammond 2005e). Geographic compartmentalization of catastrophic climatic impacts intersects with landscape legacy effects (see Table 1) that have formed through geologic, paleoclimatic, and human-use histories. Other social and economic background conditions, although more malleable, can amplify or modulate impacts of these events.
Prospects for sustainability would be limited in areas in which both current intrinsic and extrinsic background conditions work against longer-term continuity in management delivery.

\section{CONCLUSION}

Intersecting different background conditions for any given forest area would create profiles depicting varying factors imposing risks upon prospects for achieving sustainability under an adopted management scenario. Mapping how these vary spatially might identify geographic risk topologies that are not currently addressed in processes undertaken to identify the best approach to forest management. Although we have only briefly explored a subset of these effects, and analyzed the spatial discriminatory power of only one, albeit important, condition, multidisciplinary evidence indicates that background conditions at any given time should vary with the geographic change in the biophysical and socioeconomic drivers that deliver these conditions. Identifying relatively rapid changes, or inflections, in background conditions might be useful in identifying appropriate scales for tailoring sustainable forest management and which components of forest management are robust or highly sensitive to these changes. Assessing how these conditions are interlinked through cause-andeffect and/or collinear relationships should help in identifying factors that weigh the most heavily in answering how policies and practices should change with spatial scale to provide the best opportunities for reaching sustainability benchmarks. In some instances, risk profiles may indicate that a form of " quasi-sustainability, might be better suited to deliver some key precursor benefits to some user groups, with management systems reflecting these less grandiose benchmarks. Other areas with lower risk profiles may be better suited to more rigorously tailored management systems. In this way, relative management achievements can be weighted by conditions outside the remit of forest managers.

By spatially discriminating the relative importance of conditions across tropical forestlands, more robust management frameworks can be tailored to better overcome misaligned policy-making and implementation bottlenecks and deliver benefits. A constructive approach for integrating these effects into decision-making processes may best be delivered by: 
1. identifying a core basket of the most influential and independent extrinsic and intrinsic background conditions,

2. constructing spatial coverage of background conditions as factors imparting risk to successful implementation,

3. resolving probability maps outlining the spatial variation in likelihood of achieving sustainable management benchmarks for different forest use opportunities based on (1) and (2), and

4. developing optimal forest land use pathways and objectives after being conditioned upon background conditions.

Overcoming these barriers is crucial in achieving progress toward sustainable forest management and making forest resources work optimally toward alleviating poverty, leveraging local and national socioeconomic development, yet avoiding longterm degradation of important forest-based goods and services.

Responses to this article can be read online at: http://www.ecologyandsociety.org/voll1/iss 1/art37/responses/

\section{Acknowledgments:}

The authors wish to thank the editorial staff and two reviewers for their helpful comments and constructive arguments in revising earlier versions of this paper.

\section{LITERATURE CITED}

Aalto, R., L. Maurice-Bourgoin, T. Dunne, D. R. Montgomery, C. A. Nittrouer, and J. L. Guyot. 2003. Episodic sediment accumulation on Amazonian flood plains influenced by El Niño/ Southern oscillation. Nature 425:493-497.

Achard, F., H. D. Eva, H.-J. Stibig, P. Mayaux, J. Gallego, T. Richards, and J.-P. Malingreau. 2002. Determination of deforestation rates of the world's humid tropical forests. Science 297:999-1002.

Adams, R. H. 2003. International migration, remittances, and the brain drain. World Bank, Washington, D.C., USA.

Anyamba, A., C. J. Tucker, and R. Mahoney. 2002. From El Niño to La Nina: vegetation response patterns over east and southern Africa during the 1997-2000 period. Journal of Climate 15:3096-3103.

Asner, G. P., D. E. Knapp, E. N. Broadbent, P. J. C. Oliveira, M. Keller, and J. M. N. Silva. 2005. Selective logging in the Brazilian Amazon. Science 310:480-482.

Baker, T. R., M. D. Swaine, and D. F. Burslem. 2003. Variation in tropical forest growth rates: combined effects of functional group composition and resource availability. Perspectives in Plant Ecology, Evolution and Systematics 6:21-36.

Barbier, E. B., and G. R. Conway. 1990. After the green revolution: sustainable agriculture for development. Earthscan, London, UK.

Barbier, E. B. 1991. The economic value of ecosystems: 2: tropicalforests. LEEC, London, UK.

Barbier, E. B., J. C. Burgess, J. Bishop, and B. Aylward. 1994. The economics of the tropical timber trade. Earthscan, London, UK.

Barham, B. L., and O. T. Coomes. 1996. Prosperity's promise: the Amazon rubber boom and distorted economic development. Westview, Boulder, Colorado, USA.

Barreto, P.,P. Amaral, E. Vidal, and C. Uhl. 1988. Costs and benefits of forest management for timber production in eastern Amazonia. Forest Ecology and Management 108:9-26.

Bennett, E. L., and M. T. Gumal. 2001. The interrelationships of commercial logging, hunting and wildlife in Sarawak. Pages 359-374 in J. G. Robinson, editor. The cutting edge, conserving wildlife in logged forests. Columbia University Press, New York, New York, USA.

Berkes, F., J. Colding, and C. Folke. 2000. Rediscovery of traditional ecological knowledge as adaptive management. Ecological Applications 10:1251-1262. 
Bojanic, A. J. 2001. Balance is beautiful: assessing sustainable development in the rain forests of the Bolivian Amazon. PROMAB, Utrecht, The Netherlands.

Boltz, F., T. P. Holmes, and D. R. Carter. 2003. Economic and environmental impacts of conventional and reduced-impact logging in tropical South America: a comparative review. Forest Policy and Economics 5:69-81.

Boot, R. G. A. 1996. The significance of seedling size and growth rate of tropical forest seedlings for regeneration in canopy openings. Pages 267-284 in M. D. Swaine, editor. The ecology of tropical forest tree seedlings. Parthenon, Paris, France.

Brown, S., C. A. S. Hall, W. Knabe, J. Raich, M. C. Trexler, and P. Woomer. 1993. Tropical forests: their past, present and potential future role in the terrestrial carbon budget. Water, Air, and Soil Pollution 70:71-94.

Bunker, S. G. 1985. Underdeveloping the Amazon - extraction, unequal exchange, and the failure of the modern state. University of Illinois Press, Chicago, Illinois, USA.

Buschbacher, R. J. 1986. Tropical deforestation and pasture development. Bioscience 36:22-28.

Buschbacher, R. J. 1990. Natural forest management in the humid tropics: ecological, social, and economic considerations. Ambio 19:253-258.

Carpenter, R. A., editor. 1981. Assessing tropical forest lands: their suitability for sustainable uses. Tycooly International, Dublin, Ireland.

Chai, D. N. P., and M. P. Udarbe. 1977. The effectiveness of current silvicultural practice in Sabah. Malaysian Forester 40:27-35.

Chanderballi, A. S., H. van der Werff, and S. S. Renner. 2001. Phylogeny and historical biogeography of Lauraceae: evidence from chloroplast and nuclear genomes. Annals of the Missouri Botanical Garden 88: 104-134.

Chao, N. L., and G. Prang. 1997. Project Piabatowards a sustainable ornamental fishery in the Amazon. Aquarium Sciences and Conservation 1:105-111.
Chauvin, H. 1976. Opening up the tropical moist forest and harvesting the timber: factors conditioning methods and costs. Unasylva 112/113:80-85.

Cochrane, M. A., and M. D. Schulze. 1999. Fire as a recurrent event in tropical forests of the Eastern Amazon: effects on forest structure, biomass, and species composition. Biotropica 31:2-16.

Cockburn, A., J. St. Clair, and K. Silverstein. 1999. The politics of "natural" disaster: who made Mitch so bad? International Journal of Health Services 29:459-462.

Colding, J., and C. Folke. 2001. Social taboos: "Invisible" systems of local resource management and biological conservation. Ecological Applications 11:584-600.

Condit, R., S. P. Hubbell, and R. B. Foster. 1996. Changes in tree species abundance in a Neotropical forest: impact of climate change. Journal of Tropical Ecology 12:231-256.

Coomes, O. T. 1995 . A century of rain forest use in western Amazonia: lessons for extraction-based conservation of tropical forest resources. Forest and Conservation History 39:108-120.

Currey, B. and G. Hugo, editors. 1984. Famine as a geographical phenomenon. D. Reidel, Dordrecht, The Netherlands.

Dai, A., and T. M. L. Wigley. 2000. Global patterns of ENSO-induced precipitation. Geophysical Research Letters 27:1283-1286.

Dargavel, J., K. E. Dixon, N. Semple, and Tropical Forest History Working Group. 1988. Changing tropical forests : historical perspectives on today's challenges in Asia, Australasia and Oceania: workshop meeting, Canberra 16-18 May 1988. Publications Section Centre for Resource and Environmental Studies, Canberra, Australia.

Dawkins, H. C., and M. S. Philip. 1998. Tropical moist forest silviculture and management: a history of success and failure. CAB International, Wallingford, UK.

de Graaf, N. R. 1986. A silvicultural system for natural regeneration of tropical rain forest in Suriname. Pudoc/WAU, Wageningen, The Netherlands. 
de Graaf, N. R., R. L. H. Poels, and R. S. A. R. van Rompaey. 1999. Effect of silvicultural treatment on growth and mortality of rainforest in Surinam, over long periods. Forest Ecology and Management 124:123-135.

Degens, E. T. 1982. Transport of carbon and minerals in major world rivers, Part 1. SCOPE/ UNEP, Hamburg, Germany.

Dickinson, M. B., J. C. Dickinson, and F. E. Putz. 1996. Natural forest management as a conservation tool in the tropics: divergent views on possibilities and alternatives. Commonwealth Forestry Review 75:309-315.

Draulans, D., and E. van Krunkelsven. 2002. The impact of war on forest areas in the Democratic Republic of Congo. Oryx 36:35-40.

Dudley, J. P., J. R. Ginsberg, A. J. Plumptre, J. A. Hart, and L. C. Campos. 2002. Effects of war and civil strife on wildlife and wildlife habitats. Conservation Biology 16:319-329.

Eichengreen, B., and P. B. Kenen. 1994. Managing the world economy under the Bretton Woods system: an overview. Pages 3-57 in P. B. Kenen, editor. Managing the world economy. Fifty years after Bretton Woods. Institute for International Economics, Washington D.C., USA.

Ek, R. C. 1997. Botanical diversity in the tropical rain forest in Guyana. Tropenbos-Guyana Programme, Wageningen, The Netherlands.

Enfield, D. B. 1996. Relationships of interAmerican rainfall to tropical Atlantic and Pacific SST variability. Geophysical Research Letters 23:3505-3508.

Fang, J., S. Piao, Z. Tang, C. Peng, W. Ji, A. K. Knapp, and M. D. Smith. 2001. Interannual Variability in Net Primary Production and Precipitation. Science 293:1723a.

FAO. 2004. Global forest resources assessment 2001. FAO, Rome, Italy.

FAOSTAT. 2003. FAOSTAT Forestry data. FAO, Rome, Italy. Available online at: http://faostat.fao. org" http://faostat.fao.org.

Fearnside,P.M. 1990. Fire in the tropical rain forest of the Amazon basin. Pages 106-116 in J. G. Goldammer, editor. Fire in the tropical biota. Springer-Verlag, Heidelberg, Germany.

Fearnside,P.M., and R.I.Barbosa. 1996. Political benefits as barriers to assessment of environmental costs in Brazil's Amazonian development planning: the example of the Jatapu dam in Roraima. Environmental Management 20:615-630.

Fimbel, R. A., A. Grajal and J. G. Robinson, editors. 2001. The cutting edge: conserving wildlife in logged tropical forests. Columbia University Press, New York, New York, USA.

Fine, P. V. A. 2002. The invasibility of tropical forests by exotic plants. Journal of Tropical Ecology 18:687-705.

Frank, K. T., B. Petrie, J. S. Choi, and W. C. Leggett. 2005. Trophic cascades in a formerly coddominated ecosystem. Science 308:1621-1623.

Freese, C. H. 1998. Wild species as commodities. Island Press, Washington, D.C., USA.

Gagnon, A. S., A. B. G. Bush, and K. E. SmoyerTomic. 2001. Dengue epidemics and the El Niño Southern Oscillation. Climate Research 19:35-43.

Gagnon, A. S., K. E. Smoyer-Tomic, and A. Bush. 2002. The El Niño Southern Oscillation and malaria epidemics in South America. International Journal of Biometeorology 46:81-89.

Garwood, N. C., D. P. Janos, and N. Brokaw. 1979. Earthquake-caused landslides: a major disturbance to tropical forests. Science 205:997-999.

Glantz, M. H. 1998. Currents of change: impacts of El Niño and La Nina on climate and society. Cambridge University Press, Cambridge, UK.

Godoy, R., K. Kirby, and D. Wilkie. 2001. Tenure security, private time preferences, and the use of natural resources among lowland Bolivian Amerindians. Ecological Economics 38:105-118.

Goodwin, A. 1996. Principles of Precambrian Geology. Academic Press, New York, New York, USA.

Graham, E. A., S. S. Mulkey, K. Kitajima, N. G. Phillips, and S. J. Wright. 2003. Cloud cover limits 
net $\mathrm{CO}_{2}$ uptake and growth of a rainforest tree during tropical rainy seasons. Proceedings of the National Academy of Sciences 100:572-576.

Hammond, D. S., and V. K. Brown. 1995. Seed size of woody plants in relation to disturbance, dispersal, soil type in wet Neotropical forests. Ecology 76:2544-2561.

Hammond, D. S., and H. ter Steege. 1998. Propensity for fire in the Guianan rainforests. Conservation Biology 12:944-947.

Hammond, D. S., P. van der Hout, R. Zagt, G. Marshall, J. Evans, and D. S. Cassells. 2000. Benefits, bottlenecks and uncertainties in the pantropical implementation of reduced impact logging techniques. International Forestry Review 2:45-53.

Hammond, D. S. 2005a. Ancient land in a modern world. Pages 1-14 in D. S. Hammond, editor. Tropical forests of the Guiana Shield. CABI, Wallingford, UK.

Hammond, D. S. 2005b. Forest conservation and management in the Guiana Shield. Pages 481-520 in D. S. Hammond, editor. Tropical forests of the Guiana Shield. CABI Publishing, Wallingford, UK.

Hammond, D. S. 2005c. Socio-economic aspects of Guiana Shield forest use. Pages 381-480 in D. S. Hammond, editor. Tropical forests of the Guiana Shield. CABI, Wallingford, UK.

Hammond, D. S. 2005d. Biophysical features of the Guiana Shield. Pages 15-194 in D. S. Hammond, editor. Tropical forests of the Guiana Shield. CABI, Wallingford, UK.

Hammond, D. S. 2005e. Guianan forest dynamics: geomorphographic control and tropical forest change across diverging landscapes. Pages 343-380 in D. S. Hammond, editor. Tropical forests of the Guiana Shield. CABI, Wallingford, UK.

Hartwick, J. M. 1977. Intergenerational equity and the investing of rents from exhaustible resources. American Economic Review 66:972-974.

Hecht, S. B. 1985. Environment, development and politics: capital accumulation, and the livestock sector in Amazonia. World Development 13:663-684.
Hilson, G. 2002. The environmental impact of small-scale gold mining in Ghana: identifying problems and possible solutions. The Geographical Journal 168:57-72.

Homma,A. K. O. 1992. The dynamics of extraction in Amazonia: a historical perspective. Advances in Economic Botany 9:23-31.

Inge, K., I., Grunberg, and M. A. Stern, editors. 1999. Global public goods: international cooperation in the 21st century. Oxford University Press/UNDP, New York, New York, USA.

Karesh, W. B., R. A. Cook, E. I. Bennett, and J. Newcomb. 2005. Wildlife trade and global disease emergence. Emerging Infectious Diseases 11:1000-1002.

Karsenty, A. 2003. Underlying causes of the rapid expansion of illegal exploitation of tropical timber. International Forestry Review 5:236-239.

Kauffman, J. B., and C. Uhl. 1990. Interactions of anthropogenic activities, fire, and rain forests in the Amazon basin. Pages 117-134 in J. G. Goldammer, editor. Fire in the tropical biota. Springer-Verlag, Heidelberg, Germany.

King, K. F. S. 1965. The use of arboricides in the management of tropical high forest. Turrialba 15:35-39.

Kirby, K. N. 1993. Advanced data analysis with SYSTAT. van Nostrand Reinhold, New York, New York, USA.

Kremen, C., J. O. Niles, M. G. Dalton, G. C. Daily, P. R. Ehrlich, J. P. Fay, D. Grewal, and R. P. Guillery. 2000. Economic incentives for rain forest conservation across scales. Science 288: 1828-1832.

Lambin, E. F., B. L. Turner II, H. Geist, S.Agbola, J. W. B. A. Angelsen, O. Coomes, R. Dirzo, G. Fischer, C. Folke, P. S. George, K. Homewood, J. Imbernon, R. Leemans, X. Li, E. F. Moran, M. Mortimore, P. S. Ramakrishnan, J. F. Richards, H. Skånes, W. Steffen, G. D. Stone, U. Svedin, T. Veldkamp, , C.Vogel, and J. Xu. 2001. The Causes of land-use and -cover change: moving beyond the myths. Global Environmental Change 11:261-269.

Laurance, W. E., and R. O. Bierregaard, editors. 1997. Tropical forest remnants: ecology, management, and conservation of fragmented communities. The 
University of Chicago Press, Chicago, Illinois, USA.

Marengo, J. 1995. Variations and change in South American streamflow. Climatic Change 31:99-117.

McNeely, J. A. 2003. Biodiversity, war and tropical forests. Journal of Sustainable Forestry 16:33.

Milliman, J. D., and R. H. Meade. 1983. Worldwide delivery of river sediment to the oceans. Journal of Geology 91:1-21.

Miranda, M., A. Blanco-Uribe, L. Hernández, and J. G. Ochoa. 1998. All that glitter is not gold: balancing conservation and development in Venezuela's frontier forests. WRI, Washington, D. C., USA.

Murty, T. S., D. Scott, and W. Baird. 2000. The 1997 El Niño, Indonesian forest fires and the Malaysian smoke problem: a deadly combination of natural and man-made hazard. Natural Hazards 21:131-144.

Natural Research Council. 1996. Upstream: salmon and society in the Pacific Northwest. National Academy Press, Washington, D.C., USA.

Nelson, B. W., V. Kapos, J. B. Adams, W. J. Oliveira, O. P. G. Braun, and I. do Amaral. 1994. Forest disturbance by large blowdowns in the Brazilian Amazon. Ecology 75:853-858.

Nemani, R. R., C. D. Keeling, H. Hashimoto, W. M. Jolly, S. C. Piper, C. J. Tucker, R. B. Myneni, and S. W. Running. 2003. Climate-driven increases in global terrestrial net primary production from 1982 to 1999 . Science 300:1560-1563.

Nickson, R., J. McArthur, W. Burgess, K. M. Ahmed, P. Ravenscroft, and M. Rahmann. 1998. Arsenic poisoning of Bangladesh groundwater. Nature 395:338.

Olson, D. M., E. Dinerstein, E. D. Wikramanayake, N. D. Burgess, G. V. N. Powell, E. C. Underwood, J. A. D'Amico, I. Itoua, H. E. Strand, J. C. Morrison, C. J. Loucks, T. F. Allnutt, T. H. Ricketts, Y. Kura, J. F. Lamoreux, W. W. Wettengel, P. Hedao, and K. R. Kassem. 2001. Terrestrial ecoregions of the world: a new map of life on Earth. Bioscience 51:933-938.
Özden, C. and M. Schiff, editors. 2006. International migration, remittances, and the brain drain. World Bank and Palgrave Macmillan, Washington, D.C., USA.

Patz, J. A., P. Daszak, G. M. Tabor, A. A. Aguirre, M. Pearl, J. Epstein, N. D. Wolfe, A. M. Kilpatrick, J. Foufopoulos, D. Molyneux, and D. J. Bradley. 2004. Unhealthy landscapes: policy recommendations on land use change and infectious disease emergence. Environmental Health Perspectives 112:1092-1098.

Pearce, D., F. E. Putz, and J. K. Vanclay. 2003. Sustainable forestry in the tropics: panacea or folly? Forest Ecology and Management 172:229-247.

Pearce, D. W., and C. Pearce. 2001. The value of forest ecosystems: a report to the secretariat of the convention on biological diversity. CBD, Montreal, Quebec, Canada.

Peña, M., and P. Zuidema. 1999. Limitaciones demográficas para el aprovechamiento sostenible de Euterpe precatoria para producción de palmito en dos tipos de bosque de Bolivia. Ecología en Bolivia 33:3-21.

Peres, C. A., C. Baider, P. A. Zuidema, L. H. O. Wadt, K. A. Kainer, D. A. P. Gomes-Silva, R. P. Salomão, L. L. Simões, E. R. N. Franciosi, F. C. Valverde, R. Gribel, G. H. J. Shephard, M. Kanashiro, P. Coventry, D. W. Yu, A. R. Watkinson, and R. P. Freckleton. 2003. Demographic threats to the sustainability of Brazil nut exploitation. Science 302:2112-2114.

Peterson, G. D., and M. Heemskerk. 2001. Deforestation and forest regeneration following small-scale gold mining in the Amazon: the case of Suriname. Environmental Conservation 28:117-126.

Philander, S. G. H. 1990. El Niño, La Nina, and the southern oscillation. Academic Press, London, UK.

Phillips, O. L., Y. Malhi, N. Higuchi, W. F. Laurance, P. V. Nunez, R. M. Vasquez, S. G. Laurance, L. V. Ferreira, M. Stern, S. Brown, and J. Grace. 1998. Changes in the carbon balance of tropical forests: evidence from long-term plots. Science 282:439-442.

Pinard, M. A., and F. E. Putz. 1993. Reduced- 
impact logging as a carbon-offset method. Conservation Biology 7:755-758.

Pons, T. L., E. E. Alexander, N. C. Houter, S. A. Rose, and T. Rijkers. 2005. Ecophysiological patterns in Guianan forest plants. Pages 195-232 in D. S. Hammond, editor. Tropical forests of the Guiana Shield CABI, Wallingford, UK.

Price, S. V., editor. 2003. War and tropical forest: conservation in areas of armed conflict. Haworth, Binghampton, New York, USA.

Primack, R., and R. Corlett. 2005. Tropical rain forests: an ecological and biogeographical comparison. Blackwell, New York, New York, USA.

Putz, F. E., G. M. Blate, K. H. Redford, R. A. Fimbel, and J. G. Robinson. 2001. Tropical forest management and conservation of biodiversity: an overview. Conservation Biology 15:7-20.

Rasmusson, E. M., and J. M. Wallace. 1983. Meteorological aspects of the El Niño/Southern Oscillation. Science 222:1195-1202.

Repetto, R., and M. Gillis, editors. 1988. Public policies and the misuse of forest resources. Cambridge University Press, Cambridge, UK.

Rice, R. E., C. A. Sugal, S. M. Ratay, and G. A. B. da Fonseca. 2001. Sustainable forest management: a review of conventional wisdom. Conservation International, Washington, D.C., USA.

Robbins, P. 2000. The rotten institution: corruption in natural resource management. Political Geography 19:423-443.

Rodan, B. D., A. C. Newton, and A. Verissimo. 1992. Mahogany conservation: status and policy initiatives. Environmental Conservation 19:331-338.

Ropelewski, C. F., and M. S. Halpert. 1987. Global and regional scale precipitation patterns associated with the El Nino/Southern Oscillation. Monthly Weather Review 115:1606-1626.

Rudel, T. 2005. Tropical forests: regional paths of destruction and regeneration in the late twentieth century. Columbia University Press, New York, New York, USA.
Salafsky, N. 1994. Drought in the rain forest: effects of the 1991 El Niño-Southern Oscillation event on a rural economy in West Kalimantan, Indonesia. Climatic Change 27:373-396.

Salo, J., R. Kalliola, I. Hakkinen, Y. Makinen, P. Niemela, M. Puhakka, and P. D. Coley. 1986. River dynamics and the diversity of Amazon lowland forest. Science 322:254-258.

Sharpe, W., G. J. Alexander, and J. W. Bailey. 1998. Investments. Prentice Hall, New York, New York, USA.

Sheil, D. 1994. Naturalized and invasive plant species in the evergreen forests of the East Usambara Mountains, Tanzania. African Journal of Ecology 32:66-71.

Sheil, D., R. Nasi, and B. Johnson. 2004. Ecological criteria and indicators for tropical forest landscapes: challenges in the search for progress. Ecology and Society 9:7.

Siegert, F., G. Ruecker, A. Hinrichs, and A. A. Hoffman. 2001. Increasing damage from fires in logged forests during droughts caused by El Niño. Nature 414:437-440.

Sist, P., T. Nolan, J.-G. Bertault, and D. Dykstra. 1998. Logging intensity versus sustainability in Indonesia. Forest Ecology and Management 108:251-260.

Smith, W. 2002. The global problem of illegal logging. Tropical Forest Update 12:1-5.

Snook, L. K. 1996. Catastrophic disturbance, logging and the ecology of mahogany (Swietenia macrophylla King): grounds for listing a major tropical timber species in CITES. Botanical Journal of the Linnean Society 122:35-46.

Sunderlin, W. D., and S. Wunder. 2000. The influence of mineral exports on the variability of tropical deforestation. Environment and Development Economics 5:309-322.

Sunderlin, W. D., A. Angelsen, B. Belcher, P. Burgers, R. Nasi, L. Santoso, and S. Wunder. 2005. Livelihoods, forests, and conservation in developing countries: an overview. World Development 33:1383-1402. 
Systat. 1998. Systat 8.0 Statistics. SPSS, Chicago, Illinois, USA.

ter Steege, H. 1998. Biomass estimates for forests in Guyana and their use in carbon offsets. Iwokrama International Centre, Georgetown, Guyana.

ter Steege, H., and D. S. Hammond. 2001. Character convergence, diversity, and disturbances in tropical rain forest in Guyana. Ecology 82:3197-3212.

U.S. Bureau of Mines (USGS). 2004. Mineral yearbook Volume III: area reports: international \& commodity summaries. USGS, Washington, D.C., USA.

van Gemerden, B. S., H. Olff, M. P. E. Parren, and F. Bongers. 2003. The pristine rain forest? Remnants of historical human impacts on current tree species composition and diversity. Journal of Biogeography 30:1381-1390.

Verburg, R., H. ter Steege, and R. J. Zagt. 2003. Long-term changes in tropical tree diversity: synthesis and implications for management. Pages 175-191 in H. ter Steege, editor. Long term changes in tropical tree diversity. Tropenbos International, Wageningen, The Netherlands.

Vincent, J. R. 1990. Rent capture and the feasibility of tropical forest management. Land Economics 66:212-223.

Vincent, J. R., and M. Gillis. 1998. Deforestation and forest land use: a comment. The World Bank Research Observer 13:133-140.

Wadsworth, F. H. 1959. Effects of the 1956 hurricane on forests in Puerto Rico. Caribbean Forester 20:38-51.

Webb, L. J. 1958. Cyclones as an ecological factor in the tropical lowland rain forest, North Queensland. Australian Journal of Botany. 6:220-230.

Whitmore, T. C. 1974. Change with time and the role of cyclones in tropical rain forest on Kolombangara, Solomon Islands. Commonwealth Forestry Institute Paper 46, Commonwealth Forestry Institute, Oxford, UK.
Whitmore, T. C., and J. N. M. da Silva. 1990. Brazil rain forest timbers are mostly very dense. Commonwealth Forestry Review 69:87-90.

World Bank. 2004. World bank development indicators. World Bank, Washington, D.C., USA.

Wunder, S. 2001. Poverty alleviation and tropical forests: what scope for synergies. World Development 29:1817-1833.

Wunder, S., and W. D. Sunderlin. 2004. Oil, macroeconomics and forests: assessing the linkages. World Bank Research Observer 19:231-257.

Zarin, D. J., J. R. R. Alavalapati, F. E. Putz, and M. Schmink, editors. 2004. Working forests in the Neotropics: conservation through sustainable management? Columbia University Press, New York, New York, USA. 